\title{
Acute Fulminant Myocarditis Associated to Rhinovirus-Human Herpes Virus-7 (HHV-7) Co-infection in a Child
}

\section{Çocuk Hastada Rinovirüs-Insan Herpes Virüsü-7 (HHV-7) Ko-enfeksiyonu Illişkili Akut Fulminan Miyokardit} \author{
Gülşen Akkoç5, Dursun Murat Alada ${ }^{6}$ \\ ' Unite of Pediatric Intensive Care, Van Training and Research Hospital, Van, Turkey \\ ${ }^{2}$ Clinic of Pediatric Cardiovascular Surgery, Van Training and Research Hospital, Van, Turkey \\ ${ }^{3}$ Clinic of Pediatrics, Van Training and Research Hospital, Van, Turkey \\ ${ }^{4}$ Clinic of Pediatric Cardiology, Van Training and Research Hospital, Van, Turkey \\ ${ }^{5}$ Clinic of Pediatric Infectious Diseases, Van Training and Research Hospital, Van, Turkey \\ ${ }^{6}$ Division of Medical Microbiology, Erzurum Obstetric Hospital, Van, Turkey
}

Osman Yeşilbaş ${ }^{1}$, Emrah Şişli², Ela Cem ${ }^{3}$, Mehmet Gökhan Ramoğlư ${ }^{4}$, Özlem Kahraman Çayan ${ }^{3}$, Can Polat ${ }^{3}$,

Cite this article as: Yeşilbaş O, Şişli E, Cem E, Ramoğlu MG, Kahraman Çayan Ö, Polat C, et al. Acute fulminant myocarditis associated to rhinovirus-human herpes Virus-7 (HHV-7) Co-infection in a child. J Pediatr Inf 2019;13(2):e83-e87

\section{Abstract}

Rhinovirus, a member of the Picornaviridae family, is usually the cause of common cold with the symptoms of rhinorrhea, nasal congestion, cough, sneezing, sore throat, and headache. In the current literature, it is remarked that rhinovirus can lead to fatal lower respiratory tract infections, acute respiratory distress syndrome, and myocarditis. Human herpes virus-7 (HHV-7), which was first described in 1990, is the cause of exantem subitum, coryza, acute infantile hemiplegia, and hepatitis. In a recent article, it has been reported that HHV-7 can be an agent of myocarditis. In this report, we present a child diagnosed with fulminant myocarditis due to co-infection of rhinovirus and HHV-7, in whom extracorporeal membrane oxygenation (ECMO) was utilized. To the best of our knowledge, this is the first fulminant myocarditis case caused by a co-infection rhinovirus and HHV-7.

Keywords: Fulminant myocarditis, rhinovirus, human herpes virus-7, co-infection, extracorporeal membrane oxygentaion
Öz

Picornaviridae ailesinden olan rinovirüs sıklıkla burun akıntısı, burun tıkanıklığı, öksürük, hapşırma, boğaz ve baş ağrısı gibi bulgulara sahip soğuk algınlığı etkenidir. Güncel dizinde rinovirüsün ölümcül alt solunum yolu enfeksiyonu, akut respiratuvar distres sendromu ve miyokardite neden olabildiği belirtilmektedir. İlk kez 1990 yılında tanımlanan insan herpes virüsü-7 (human herpes virus-7; HHV-7) ekzantem subitum, nezle, akut infantil hemipleji ve hepatit gibi hastalıklara neden olabilmektedir. Yeni yayınlanmış bir çalışmada bu virüsün de miyokarditte etken olabildiği belirtilmiştir. Bu raporda, rinovirüs ile HHV-7 ko-enfeksiyonunun sebep olduğu ve ekstrakorporeal membran oksijenasyonu (ECMO) uygulanan fulminan miyokarditli çocuk hasta sunulmuştur. Ulaşabilir Türkçe ve İngilizce dizine göre hastamız etken olarak rinovirüs-HHV-7 ko-enfeksiyonu saptanan ilk fulminan miyokardit olgusudur.

Anahtar Kelimeler: Fulminan miyokardit, rinovirüs, insan herpes virüsü-7, ko-enfeksiyon, ekstrakorporeal membran oksijenasyonu

\section{Correspondence Address / Yazışma Adresi \\ Osman Yeşilbaş \\ Van Eğitim ve Araştırma Hastanesi, \\ Çocuk Yoğun Bakım Ünitesi \\ Van-Türkiye \\ E-mail: drosmanyesilbas@gmail.com}




\section{Introduction}

There are more than a hundred serotypes or rhinoviruses from the Picornaviridae family. They are relatively small (24-30 $\mathrm{nm}$ ), simple structured viral capsular and single-stranded RNA viruses. Rhinoviruses are causes of common cold with symptoms such as rhinorrhea, nasal congestion, cough, sneezing, sore throat, and headache $(1,2)$. Apart from the common cold, they can lead to otitis media and sinusitis at every age and lower respiratory tract infections (LRTI) during the neonatal period, in the elderly and in individuals with immunodeficiencies. Moreover, rhinoviruses can be detected as an agent in acute exacerbation in asthma, chronic obstructive pulmonary disease, and cystic fibrosis $(2,3)$. It has been reported in recent studies that rhinovirus can cause LRTI with a high rate of malformation and mortality, acute respiratory distress syndrome (ARDS) and myocarditis along with self-limiting infections (4-8). Human herpes virus-7 (HHV-7) defined in 1990 for the first time can lead to exantem subitum, coryza, acute infantile hemiplegia, and hepatitis. In a newly published study, this virus has also been confirmed to cause myocarditis (9).

Myocarditis, which is the inflammatory disease of the cardiac muscle, frequently occurs as a result of direct damage of the viruses or immune-mediated indirect damage of the viruses. Fulminant myocarditis (FM) with acute onset can bring about fatal arrhythmia and sudden death emerging with hemodynamic insufficiencies that necessitate inotropic and/or extra-corporeal life support treatments (10). This report aimed to present a child with FM caused by rhinovirus and HHV-7 co-infection and was put on extra-corporeal membrane oxygenation (ECMO).

\section{Case Report}

A ten-month-old male patient admitted the Pediatric Intensive Care Unit (PICU) for respiratory distress. It was learned that the patient had been having complaints of fast breathing and fatigue for the last two days. The patient, who was a full- term newborn with normal spontaneous birth and a weight of $3060 \mathrm{~g}$, had been admitted to hospital twice before due to acute bronchiolitis. There was no blood group incompatibility between the mother and father. On physical examination, the patient was inclined to sleep, lost interest to his surrounding and his Glasgow Coma Score (GCS) was 12. Body temperature and blood pressure of the patient who was tachycardic (182/ $\mathrm{min}$ ) and tachypneic $(68 / \mathrm{min})$ were $37.3^{\circ} \mathrm{C}$ and $70 / 36 \mathrm{mmHg}$ (sub-limit for systolic blood pressure according to age is 70 $\mathrm{mmHg}$ ), respectively. Capillary refill time was long (4 sec). Pathological sound was not heard in the lung occultation of the patient whose oxygen saturation was $99 \%$ while receiving oxygen $10 \mathrm{~L} / \mathrm{min}$ with reservoir non-rebreather mask. In abdominal examination, hepatomegaly $3-\mathrm{cm}$ in size was detected under the rib. Weight, height and head circumference percentiles were within the appropriate range for his age. Leukocytosis was found $\left(23.660 / \mathrm{mm}^{3}\right.$, neutrophil: $15.140 /$ $\mathrm{mm}^{3}$, lymphocyte: $7370 / \mathrm{mm}^{3}$ ) in the whole blood count of the patient whose blood gas results were as follows: $\mathrm{pH}: 7.20$, $\mathrm{PaCO}_{2}: 38 \mathrm{mmHg}, \mathrm{hCO}_{3}: 14.6 \mathrm{mEq} / \mathrm{L}$, base deficit: -13.1, lactate: $5 \mathrm{mmol} / \mathrm{L}$ (normal: $0.5-1.6 \mathrm{mmol} / \mathrm{L}$ ). Biochemistry analysis was normal apart from creatinine kinase (CK)-MB elevation (63.6 $\mathrm{U} / \mathrm{L}$, normal: 0-25 U/L). C-reactive protein and procalcitonin level were within normal limits. Chest X-Ray revealed cardiomegaly (Figure $1 \mathrm{~A}$ ). Echocardiography (ECO) showed significantly enlarged left cardiac cavity with left ventricle being more prominent, septum deviated to the right, mild to severe atrioventricular valve insufficiency, and significantly reduced left ventricle systolic functions [ejection fraction (EF) 21\%] (Figure 2A). After intubating the patient, who was diagnosed with FM due to respiratory distress and cardiac failure, the patient was put to mechanic ventilator (MV) support under sedation-analgesia (midazolam + ketamine). Central venous and arterial catheter were opened. Intravenous immunoglobulin (IVIG) treatment was started (1 $\mathrm{g} / \mathrm{kg} /$ dose and two days). Adrenaline and dobutamine infusion were commenced for
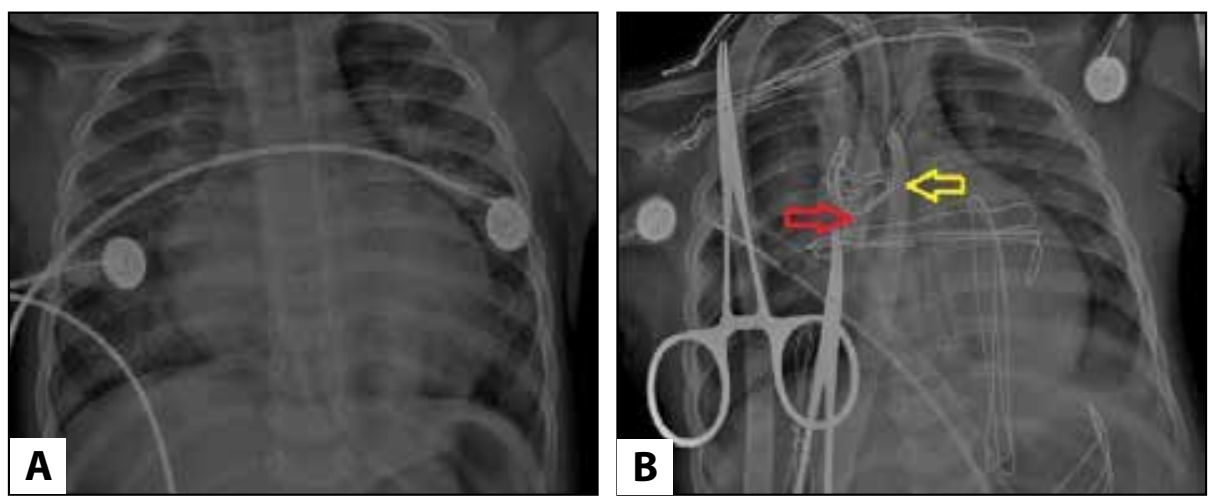

Figure 1. (A) Cardiomegaly image in the lung graphy of the patient on first admittance. (B) The imaging of cannulae placed to the right atrium (red arrow) and to the ascending aorta (yellow arrow) for central venoarterial extracorporeal membrane oxygenation on the lung graphy. 

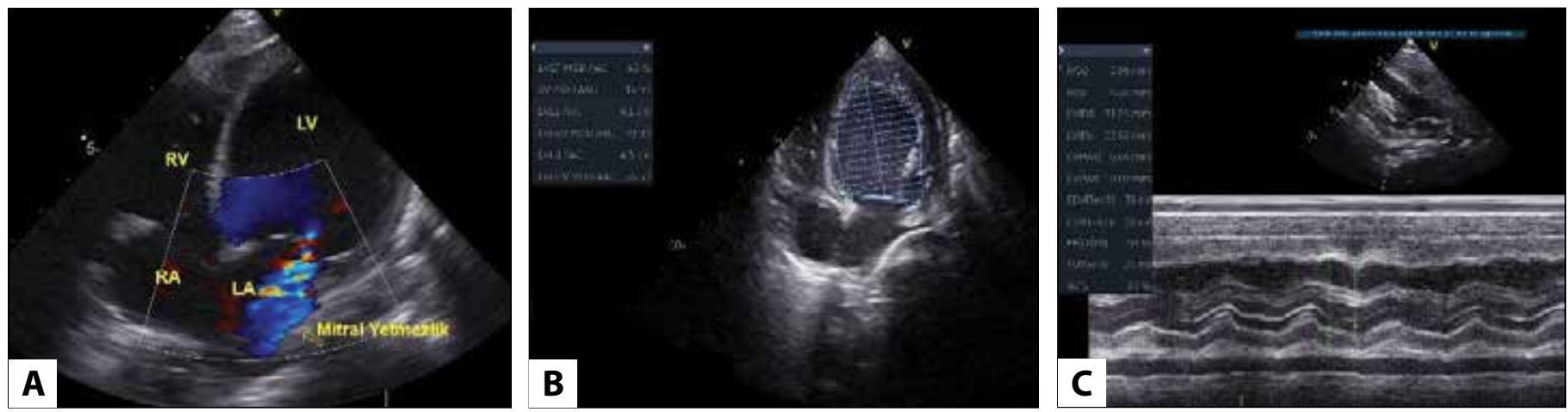

Figure 2. (A) Echocardiography imaging on the first admittance of the patient. Significantly enlarged left cardiac cavity with left ventricle being more prominent, septum deviated to the right, mild to severe atrioventricular valve insufficiency, and significantly reduced left ventricle systolic functions (B) Image of the echocardiography where left ventricle ejection fraction was $43 \%$ on day 9 . (C) Image of the echocardiography where left ventricle ejection fraction was $54 \%$ on day 19 .

RV: Right ventricle, RA: Right atrium, LV: Left ventricle, LA: Left atrium.

hemodynamic and inotropic support. Doses were dynamically regulated according to blood pressure, lactate level and circulatory examination. Noradrenalin infusion was added to the treatment of the patient whose blood pressure dropped and lactate level increased, and its dose was adjusted according to blood pressure. Upon persistence of hypotension and circulatory disorder despite all hemodynamic support treatments, urgent ECMO application was decided. Cardiopulmonary resuscitation (CPR) was successfully performed for five minutes on the patient who was transferred to the operating room and developed cardiac arrest, and heart beat in sinus rhythm was achieved. Cannula was placed to the right atrium (24Fr, dlp, Medtronic $\left.{ }^{\circledast}\right)$ and to the ascending aorta (12Fr dlp, Medtronic $^{\circledR}$ ) with urgent sternotomy (Figure 1B). The sternum was left open, the skin was closed with membrane. ECMO flow rate was regulated dynamically as regards to oxygenation, blood pressure, lactate and echocardiographic monitoring. Inotrope and vasopressor dose and MV pressures were decreased. Nose swab sample was taken for virologic examination aimed at etiology. In order to investigate respiratory viruses, multiplex real-time polymerase chain reaction (PCR) method was performed using FTD Respiratory Pathogens $21^{\circledR}$ (Fast-Track Diagnostics, Luxembourg) kit on Rotorgene $3000^{\circledR}$ (Qiagen, Australia) device. While rhinovirus and HHV-7 were found positive in the respiratory viral panel, the other agents (Mycoplasma pneumoniae, coxackie $A-B$, influenza virus $A-B$, parainfluenza virus 1-4, bocavirus, coronavirus OC43-NL63-229E-HKU1, respiratory syncytial virus $A-B$, metapneumovirus, adenovirus, enterovirus, paraecovirus, parvovirus, rubeola virus and HHV-6) were found negative. Although there was no growth in blood and tracheal aspirate cultures, teicoplanin and meropenem treatment was started due to the rise in the body temperature and acute phase signs on the second day. The patient, whose ECMO support was progressively reduced, was taken off ECMO on the ninth day when left ventricle EF was at the level of $43 \%$ (Figure 2B). The cannulae were removed and the sternum closed. Milrinone and levosimendan infusion was started initiated. The patient was extubated on the sixteenth day of admission. By progressively decreasing inotropic drug infusions, they were terminated when left ventricle EF was $54 \%$ on day 19 (Figure 2C). The patient, whose cardiac functions were ameliorating, was lost on day 25 of admission due to sepsis and multiple organ failure. Written informed consent was received from the parent of the patient who participated in this case.

\section{Discussion}

Rhinoviruses, agents of more than $50 \%$ of the upper respiratory tract infections, cause common cold that frequently heal spontaneously within 5-7 days. There is no special medical treatment or vaccination, and the only option is supportive care in their self-limiting diseases (11). Moreover, recent studies and reports have demonstrated that this virus is not as innocent as presumed to be, which can cause life-threatening diseases (4-8). In a study from Vietnam, rhinovirus was detected in 12 children living in orphanages who were admitted to hospital due to severe LRTI between December 2007 and February 2008. In all children at the age of 2-4 months, MV and ARDD developed despite the use of wide-spectrum antibiotics and 7 died (4). Louie et al. determined that rhinovirus was the most common (49\%) as the agent in 43 children admitted to the PICU for LRTI between February and October, 2007 (5). They emphasized that children in whom rhinovirus had been detected were at younger ages (mean 1.4 years). In a report by Ceylan et al. from our country, they have specified that ARDD developed in a three-month child patient secondary to rhinovirus, and the patients was successfully treated with lung protective MV strategy (6). In the literature, cardiac involvement of rhinovirus is rare. Thanh et al. have presented 
a case of non-fulminant myocarditis secondary to rhinovirus in a 13-year-old female child patient (7). The authors have indicated that this patient successfully ameliorated without any sequel with medical therapy without the need to ECMO support. Kanık-Yüksek et al. from our country have reported pericardial effusion that regresses spontaneously in a four-monthold child treated in hospital for bronchiolitis secondary to rhinovirus (12). Tapparel et al. have presented a 14-month-old male patient who was treated for pneumonia and pericarditis coexistence, and in whom rhinovirus was detected as the agent (13). FM was present in our patient without pericarditis or pericardial effusion. Compatible with the literature, our patient who developed FM secondary to rhinovirus and HHV-7 coinfection was at a very young age.

There is only one study found in Turkish and English literature regarding myocarditis associated with human herpes viris-7. In a study by Özdemir et al., HHV-7 was detected as a result of the PCR test performed on blood samples of four children out of eight with a diagnosis of myocarditis (9). They have indicated that two of these four patients presented to the clinic with dilated cardiomyopathy (9). PCR examinations could have been performed in the endomyocardial biopsy material with plasma in order to prove if this two-virus co-infection was the real agent of FM in our patient. However, not every analysis could be performed due to technical impossibilities.

Besides inotropic medication to support circulation in FM that develops acutely, progression is fast and manifests itself with signs of severe cardiac failure (dyspnea, edema, chest pain, progressive fatigue), and extracorporeal life support system may be needed. Benign or fatal arrhythmia and even sudden death can be seen in some patients. In history, before the onset of the disease, URTI supporting viral etiology and a prodromal period with enteritis findings are mostly present (10). Successful CPR was performed after sudden cardiac arrest in our patient who did not have a prodromal period. Furthermore, ECMO was successfully applied to the patient whose circulatory disorder and hypotension continued in spite of intense hemodynamic supportive care. In the children's age group, many cardiotropic viruses, particularly Coxsackie viruses are responsible for the etiology of FM. Direct cytotoxicity and/or autoimmunity triggered by the virus are responsible for the emergence of the disease $(10,14)$. Electrocardiogram findings including increased acute phase indicators, increased CK-MB, pro-brain natriuretic peptide (BNP), troponin I and T levels and T and ST wave changes are seen as laboratory findings. However, the sensitivity and specificity of these findings are rather low. CK-MB level of our patient, who had leukocytosis, was high even though his acute phase indicators were normal. Since there is no pro-BNP kit in our hospital, the test could not be performed. ECHO is essential to exclude non-in- flammatory cardiac diseases and for the diagnosis and treatment plan. In the echocardiographic examination, severely reduced bi-ventricular systolic function, increase in the size of the end diastole of the ventricles, thickening of the septal wall and pericardial inflammation due to myocardial inflammation and edema can be seen (10). Other ECHO findings of our patient except for pericardial effusion were compatible with the literature. While supportive care (inotropic, extracorporeal life support systems, heart transplant if necessary) is essential in the treatment of fulminant myocarditis, immunosuppressive and immunoregulator drugs (IVIG, steroid, etc.) can be administered even though their benefits are controversial $(10,15)$. We administered IVIG therapy twice and applied ECMO to our patient.

In conclusion, it should be kept in mind that rhinovirus and HHV-7 can rarely be an agent in FM in addition to other more frequently encountered viruses. According to the accessible Turkish and English literature, our patient is the first FM case in whom rhinovirus and $\mathrm{HHV}-7$ coinfection were detected as the etiological agent.

Informed Consent: Patient consent was obtained.

Peer-review: Externally peer-reviewed.

Author Contributions: Consept - OY, EŞ; Design - OY, EŞ, MGR; Supervision - EŞ; References - EC, ÖKÇ, CP; Data Collection and/or Interpretation - GA, DMA; Analysis - EŞ, GA, DMA; Literature Search EC, ÖKÇ, CP; Writing - OY; Critical Review - EŞ.

Conflict of Interest: The authors have not reported a conflict of interest.

Financial Disclosure: There is no financial support in this study.

\section{References}

1. Demirkan E, Kırdar S, Ceylan E, Yenigün A, Kurt Ömürlü I. Genotypes of rhinoviruses in children and adults patients with acute respiratory tract infections. Mikrobiyol Bul 2017; 51:350-60.

2. Greenberg SB. Respiratory consequences of rhinovirus infection. Arch Intern Med 2003; 163:278-84.

3. Kennedy JL, Turner RB, Braciale T, Heymann PW, Borish L. Pathogenesis of rhinovirus infection. Curr Opin Virol 2012;2:287-93.

4. LeThanh Hai, Vu Thi Ngoc Bich, Le Kien Ngai, Nguyen Thi Ngoc Diep, Phan Huu Phuc, Viet Pham Hung, et al. Fatal Respiratory Infections Associated with Rhinovirus Outbreak, Vietnam. Emerg Infect Dis 2012;18:1886-8.

5. Louie JK, Roy-Burman A, Guardia-Labar L, Boston EJ, Kiang D, Padilla T, et al. Rhinovirus associated with severe lower respiratory tract infections in children. Pediatr Infect Dis J 2009;28:337-9.

6. Ceylan G, Iş̧üder R, Kara A, Gülfidan G, Ağın H, Devrim I. Rinovirüsün neden olduğu akut respiratuvar distres sendromu. J Pediatr Inf 2017;11:94-7.

7. Thanh DTM, Lien DM, Hanh LTH. Myocarditis related to rhinovirus. Int J Cardiol Res 2017;4:78-81.

8. Soni P, Rai A, Aggarwal N, Kamholz S, Yoon T, Kupfer Y. Enterovirushuman rhinovirus: a rare cause of acute respiratory distress syndrome. $J$ Investig Med High Impact Case Rep 2017;5:2324709617728526. 
9. Ozdemir R, Kucuk M, Dibeklioglu SE. Report of a myocarditis outbreak among pediatric patients: human herpesvirus 7 as a causative agent? J Trop Pediatr 2018;64:468-71.

10. Veronese $G$, Ammirati E, Cipriani M, Frigerio M. Fulminant myocarditis: characteristics, treatment, and outcomes. Anatol J Cardiol 2018;19:27986.

11. Blaas $D$, Fuchs R. Mechanism of human rhinovirus infections. Mol Cell Pediatr 2016;3:21.

12. Kanik-Yuksek S, Tezer H. Pericardial effusion associated with rhinovirus infection in an immunocompetent infant. Indian Pediatr 2014;51:837-8.
13. Tapparel C, L'Huillier AG, Rougemont AL, Beghetti M, Barazzone-Argiroffo C, Kaiser L. Pneumonia and pericarditis in a child with HRV-C infection: a case report. J Clin Virol 2009;45:157-60.

14. Calabrese F, Thiene G. Myocarditis and inflammatory cardiomyopathy: microbiological and molecular biological aspects. Cardiovasc Res 2003;60:11-25.

15. Frey T, Arain N. Pediatric viral myocarditis - A review. S D Med 2018;71:2934. 